\title{
Antimelanogenesis Effects of Leaf Extract and Phytochemicals from Ceylon Olive (Elaeocarpus serratus) in Zebrafish Model
}

\author{
Chi-Ya Huang ${ }^{1}$, I-Hsuan Liu ${ }^{2}$, Xiang-Zhe Huang ${ }^{1}$, Hui-Jen Chen ${ }^{1}$, Shang-Tzen Chang ${ }^{1}$, Mei-Ling Chang ${ }^{3}$, \\ Yu-Tung Ho ${ }^{1}$ and Hui-Ting Chang ${ }^{1, *}$ \\ 1 School of Forestry and Resource Conservation, National Taiwan University, Taipei 106, Taiwan; \\ r99625047@ntu.edu.tw (C.-Y.H.); r01625054@ntu.edu.tw (X.-Z.H.); r93625033@ntu.edu.tw (H.-J.C.); \\ peter@ntu.edu.tw (S.-T.C.); b04605047@ntu.edu.tw (Y.-T.H.) \\ 2 Department of Animal Science and Technology, National Taiwan University, Taipei 106, Taiwan; \\ ihliu@ntu.edu.tw \\ 3 Department of Food Science, Nutrition, and Nutraceutical Biotechnology, Shih Chien University, \\ Taipei 104, Taiwan; mlchang@g2.usc.edu.tw \\ * Correspondence: chtchang@ntu.edu.tw; Tel.: +886-2-3366-5880
}

Citation: Huang, C.-Y.; Liu, I-H.; Huang, X.-Z.; Chen, H.-J.; Chang, S.-T.; Chang, M.-L.; Ho, Y.-T.; Chang, H.-T. Antimelanogenesis Effects of Leaf Extract and Phytochemicals from Ceylon Olive (Elaeocarpus serratus) in Zebrafish Model. Pharmaceutics 2021, 13, 1059. https://doi.org/10.3390/ pharmaceutics13071059

Academic Editors: Maria

Camilla Bergonzi, Charles M. Heard and Javier Garcia-Pardo

Received: 26 June 2021

Accepted: 9 July 2021

Published: 10 July 2021

Publisher's Note: MDPI stays neutral with regard to jurisdictional claims in published maps and institutional affiliations.

Copyright: (c) 2021 by the authors. Licensee MDPI, Basel, Switzerland. This article is an open access article distributed under the terms and conditions of the Creative Commons Attribution (CC BY) license (https:// creativecommons.org/licenses/by/ $4.0 /)$.

\begin{abstract}
The melanogenesis inhibition effect in zebrafish (Danio rerio) and antityrosinase activity of the ethanolic extract and its phytochemicals from Ceylon olive (Elaeocarpus serratus Linn.) leaves were investigated in this study. Among the leaf extract and four soluble fractions, the ethyl acetate soluble fraction exhibits the best antityrosinase and antimelanogenesis activities. One phenolic acid, gallic acid, and two flavonoids, myricetin and mearnsetin, are isolated from the active subfractions through the bioassay-guided isolation; their structures are elucidated based on the 1D and 2D NMR, FTIR, UV, and MS spectroscopic analyses. These compounds have significant antityrosinase activity whether using L-tyrosine or L-DOPA as the substrate; mearnsetin shows the optimal activity. In the enzyme kinetic investigation, both gallic acid and mearnsetin are the competitive-type inhibitors against mushroom tyrosinase, and myricetin acts as a mixed-type tyrosinase inhibitor. Leaf extract and an ethyl acetate soluble fraction show effective performance in the inhibition of melanin formation in zebrafish embryos. Mearnsetin also possesses a promising antimelanogenesis effect, which is superior to the positive control, arbutin. Results reveal that the Ceylon olive leaf extract and its phytochemicals, especially mearnsetin, have the potential to be used as antimelanogenesis and skin-whitening ingredients.
\end{abstract}

Keywords: antimelanogenesis effect; Elaeocarpus serratus; melanin; tyrosinase inhibitor; zebrafish

\section{Introduction}

Melanin plays an essential role in many biochemical functions; it provides protection for the skin from ultraviolet (UV) damage, the elimination of reactive oxygen species (ROS), and other biochemical reactions [1-3]. The excessive accumulation of melanin also brings about the hyperpigmentation, melasma, age spots, skin darkening, etc. [4,5]. In the eastern world, people are interesting in the issue of the whitening effect on the skin; the cosmetic industry is dedicated to developing skin-whitening cosmetics against melanogenesis. There are several mechanisms, including tyrosinase inhibitory activity, melanocyte removal, and interference with melanin synthesis to exhibit melanogenesis inhibitory activity. The promising reagents inhibiting melanogenesis have been investigated since the 1940s [2,4,6,7]. However, part melanogenesis inhibitors possess some side effects; e.g., hydroquinone may cause exogenous ochronosis and permanent hypomelanosis [5,8]. Excessive kojic acid may result in allergy and thyroid tumor [9,10].

Recently, researchers have been dedicated to finding promising melanogenic reagents with no/mild side effects from plant natural products [11-13]. Natural tyrosinase inhibitors from plant sources have been reported, including simple phenols, phenolic acids, 
stillbenes, flavonoids, lignans, terpenoids, quinoids, etc. [2,14-16]. Solano et al. stated that phenolic compounds and the other natural compounds have the great potential for melanin inhibition, e.g., arbutin (a phenol glucoside found in Arctostaphylos uva-ursi), the extract of green tea, alpha hydroxyl acid (AHA), ascorbic acid, and so on [5]. Arbutin is widely used as a key ingredient of commercial whitening products on the market $[4,17]$. Gallocatechin-3-O-gallate (GCG), epigallocatechin-3-O-gallate (EGCG), and epicatechin3-O-gallate (ECG) were identified in the green tea extract; these compounds possess the good tyrosinase inhibitory efficacy [17]. Arctigenin, a lignan isolated from Fructus arctii extract, could reduce the melanin content of zebrafish (Danio rerio) embryo [18]. Lee et al. reported that the ginsenosides from Panax ginseng leaf and berry inhibit the melanogenesis of the zebrafish embryo; the active ginsenosides are ginsenoside Rh6, vina-ginsenoside R4, vina-ginsenoside R13, ginsenoside Rh23, and floralginsenoside A [19-21].

Elaeocarpus serratus Linn. (Tiliaceae), commonly called Ceylon olive, is distributed in Africa, Australia, and Southeast Asia. The pickle made of the edible fruit of Ceylon olive is common in Sri Lanka [22]. It is traditionally used to prevent head lice and dandruff in Sri Lanka. Bioactivities of E. serratus extract were evaluated in the related studies [22,23]. E. serratus leaf extract possessed antibacterial activity against Plesiomonas, Salmonella typhi, and Proteus spp. at the concentration of $400 \mu \mathrm{g} / \mathrm{mL}$ by the plate-hole diffusion assay [23]. E. serratus leaf extract had the potential of being an antitumor, antimicrobial, and pesticidal reagent in the cytotoxicity investigation of brine shrimp (Artemia salina) lethality assay; the $\mathrm{LC}_{50}$ of the leaf extract was $40 \mu \mathrm{g} / \mathrm{mL}$ against the brine shrimp [23]. Antioxidant flavonol glycosides, including myricitrin, mearnsetin 3-O- $\beta$-D-glucopyranoside, mearnsitrin, and tamarixetin 3-O- $\alpha$-L-rhamnopyranoside, were isolated and identified from the E. serratus leaf extract [22].

The objectives of this study are to evaluate the effects of E. serratus leaf extract and its fractions on antityrosinase activity (in vitro) and melanogenesis inhibition activity in zebrafish (in vivo). Bioassay-guided fractionation and isolation techniques were carried out to find the promising compounds as potential antimelanogenesis ingredients. Developments of effective antimelanogenesis ingredients can increase the optimal utilization of plant natural products in pharmaceutical and cosmetic industries.

\section{Materials and Methods}

\subsection{Plant Material and Extraction}

Ceylon olive (Elaeocarpus serratus), around 50 years old, leaves were collected from National Taiwan University, Taipei, Taiwan in September. Fresh leaves $(3.95 \mathrm{~kg})$ were extracted with $95 \%$ ethanol for 7 days at room temperature. The filtered extract was dried under reduced pressure by a rotary evaporator with a bath temperature of $50{ }^{\circ} \mathrm{C}$ [24]. The yield of leaf extract $(0.32 \mathrm{~kg})$ was $12.0 \%$ ( $w / w$ of dried weight).

\subsection{Liquid-Liquid Partition}

The extract was subjected to successive organic solvent extraction in the increasing polarity order by liquid-liquid partition $[24,25]$. The leaf extract was fractionated into $n$-hexane soluble fraction (HF, 9.1\%), ethyl acetate soluble fraction (EF, $11.3 \%), n$-butanol soluble fraction $(\mathrm{BF}, 17.3 \%)$, and water soluble fraction (WF, 31.0\%).

\subsection{Column Chromatography and Thin Layer Chromatography}

Bioactive ethyl acetate soluble fraction was further fractionated by silica gel column chromatography (CC). Open-column chromatography was carried out by stepwise elution with different ratio of $n$-hexane and ethyl acetate [26]. Nineteen subfractions (E1-E19) were obtained by thin-layer chromatography (TLC) [27]. Yields of subfractions were E1 $(1.05 \%)$, E2 $(8.21 \%)$, E3 (1.64\%), E4 (0.74\%), E5 (1.52\%), E6 (0.86\%), E7 (1.51\%), E8 (9.50\%), E9 $(7.78 \%)$, E10 (3.97\%), E11 (2.65\%), E12 (8.49\%), E13 (5.58\%), E14 (4.43\%), E15 (5.31\%), E16 $(1.14 \%)$, E17 $(1.87 \%)$, E18 (0.76\%), and E19 (2.96\%). 


\subsection{High-Performance Liquid Chromatography}

Active subfractions of ethyl acetate soluble fraction were analyzed and isolated by high-performance liquid chromatography (HPLC, L-2130, Hitachi, Tokyo, Japan) fitted with a preparative RP-18 column (Purospher ${ }^{\circledR}$, STAR RP-18 end-capped, $250 \times 10 \mathrm{~mm}$, $5 \mu \mathrm{m})$. The gradient mobile phase consisted of water (A) and acetonitrile (B). The flow rate was $3 \mathrm{~mL} / \mathrm{min}$. The elution program involved a linear gradient from 30 to $35 \% \mathrm{~B}$ in A for 0-15 min, 35 to $100 \%$ B in A by $15-25 \mathrm{~min}$, and followed by $5 \mathrm{~min}$ of equilibrium with $100 \%$ B. The eluted peaks were detected by UV detector at $254 \mathrm{~nm}[25,28]$.

\subsection{Identification of Isolated Compounds}

The structures of isolated compounds were determined and characterized by means of spectral analyses, including ultraviolet-visible spectroscopy (UV/VIS, V-550, Jasco, Tokyo, Japan), Fourier transform infrared spectroscopy (FTIR, FTS-40, Bio-rad, Hercules, CA, USA), and mass spectroscopy (MS, MAT-958, Finnigan, MA, USA). Nuclear magnetic resonance spectroscopy (NMR), including $1 \mathrm{D}\left({ }^{1} \mathrm{H}-\mathrm{NMR}, 500 \mathrm{MHz} ;{ }^{13} \mathrm{C}-\mathrm{NMR}, 125 \mathrm{MHz}\right)$ and 2D NMR (HSQC and HMBC), were recorded with a Bruker AVIII NMR spectrometer (Bruker Avance, Rheinstetten, Germany) [29-32].

\subsection{Antityrosinase Assay and Enzyme Kinetic Study}

In vitro antityrosinase assay was a spectrophotometric analysis based on the methods previously described [33-35]. L-DOPA (3,4-dihydroxyphenylalanine) and L-tyrosine were using as the substrate, respectively. In the 96-well microplates, $40 \mu \mathrm{L}$ of specimen solution and $70 \mu \mathrm{L}$ of potassium phosphate buffer $(0.1 \mathrm{M}, \mathrm{pH}$ 6.8) were mixed, which was followed by adding $50 \mu \mathrm{L}$ of $200 \mathrm{unit} / \mathrm{mL}$ mushroom tyrosinase (EC1.14.18.1) after incubation at $25^{\circ} \mathrm{C}$ for $10 \mathrm{~min}$. Then, we added $40 \mu \mathrm{L}$ of $2.5 \mathrm{mM}$ substrate (L-tyrosine/L-DOPA) into the well, and the mixture was incubated for $10 \mathrm{~min}$. After incubation, the absorbance at $475 \mathrm{~nm}$ of each well was measured by the ELISA (enzyme-linked immunosorbent assay) reader (SPECTROstar Nano, BMG LABTECH, Offenburg, Germany). The positive control was arbutin, and the number of replications was three. The percentage inhibition of the tyrosinase activity was calculated by the following equation: Inhibition $(\%)=\left[\left(\mathrm{A}_{\text {control }}-\mathrm{A}_{\text {control's blank }}\right)^{-}\right.$ $\left.\left(\mathrm{A}_{\text {sample }}-\mathrm{A}_{\text {sample's blank }}\right) /\left(\mathrm{A}_{\text {control }}-\mathrm{A}_{\text {control's blank }}\right)\right] \times 100$. Then, the half-maximal inhibitory concentration $\left(\mathrm{IC}_{50}\right)$ of the specimen was calculated from the concentration response curve.

Enzyme kinetic study is analyzed by the Lineweaver-Burk reciprocal plot of the reaction rate and the concentration of the substrate to evaluate the effect of the specimen on the affinity of the substrate and enzyme. The concentration of tyrosinase was kept constant at $200 \mathrm{unit} / \mathrm{mL}$, while substrate (L-tyrosine/L-DOPA) concentration was varied at 0.5, 0.75, $1.0,1.25$, and $1.5 \mathrm{mM}$. The reaction was similar to antityrosinase assay as described above; $40 \mu \mathrm{L}$ of specimen solution and $70 \mu \mathrm{L}$ of potassium phosphate buffer $(0.1 \mathrm{M}, \mathrm{pH} 6.8)$ were mixed, which was followed by adding $50 \mu \mathrm{L}$ of $200 \mathrm{unit} / \mathrm{mL}$ tyrosinase, after incubation at $25^{\circ} \mathrm{C}$ for $10 \mathrm{~min}$. Then, we added $40 \mu \mathrm{L}$ of substrate into the well and mixed thoroughly, and kinetic measurements of the solution were measured immediately for a period of $3 \mathrm{~min}$ at the detected wavelength $(475 \mathrm{~nm})$. Both kinetic parameters, Michaelis-Menten constant $\left(\mathrm{K}_{\mathrm{m}}\right)$ and maximum velocity $\left(\mathrm{V}_{\max }\right)$, were calculated from the Lineweaver-Burk linear equation [36-38].

\subsection{Evaluation of Antimelanogenesis Effect in Zebrafish}

Zebrafish (Danio rerio) of wild-type $\mathrm{AB}$ strain were maintained in a healthy aquatic environment at $26-30{ }^{\circ} \mathrm{C}$, with a $14: 10 \mathrm{~h}$ light-dark cycle. After $9 \mathrm{~h}$ post fertilization (hpf), embryos were placed into a 24-well plate ( 3 embryos per well), treated with various final concentrations of specimens dissolved in $1 \%$ DMSO, and incubated at $28^{\circ} \mathrm{C}$ for $48 \mathrm{~h}$ (at $57 \mathrm{hpf}$ ). The digital image of live zebrafish embryo was taken through a stereomicroscope (Olympus SZ61, Tokyo, Japan) at a total magnification of 40×; then, the melanin content of zebrafish embryo was analyzed by the ImageJ software. Positive controls were arbutin 
(commercial skin whitening ingredient) and 1-phenyl-2-thiourea (PTU, a melanin synthesis inhibitor). The number of replications was six [21,39,40].

\subsection{Statistical Analysis}

Data obtained in the study were analyzed by Statistical Analysis System (SAS) v 9.2 (Cary, NC, USA) with the Scheffe's test, which is a post hoc multiple comparison method. The confidence interval was set at $95 \%$.

\section{Results and Discussion}

\subsection{Antityrosinase Activity of E. serratus Leaf Extract and Its Fractions}

The schematic diagram of extraction, isolation, identification, antityrosinase activity, and antimelanogenesis effect of E. serratus leaf extract is shown in Figure 1. The leaf extract was furtherly fractionated into $n$-hexane soluble fraction (HF), ethyl acetate soluble fraction (EF), n-butanol soluble fraction (BF), and water soluble fraction (WF) by liquid-liquid partition.

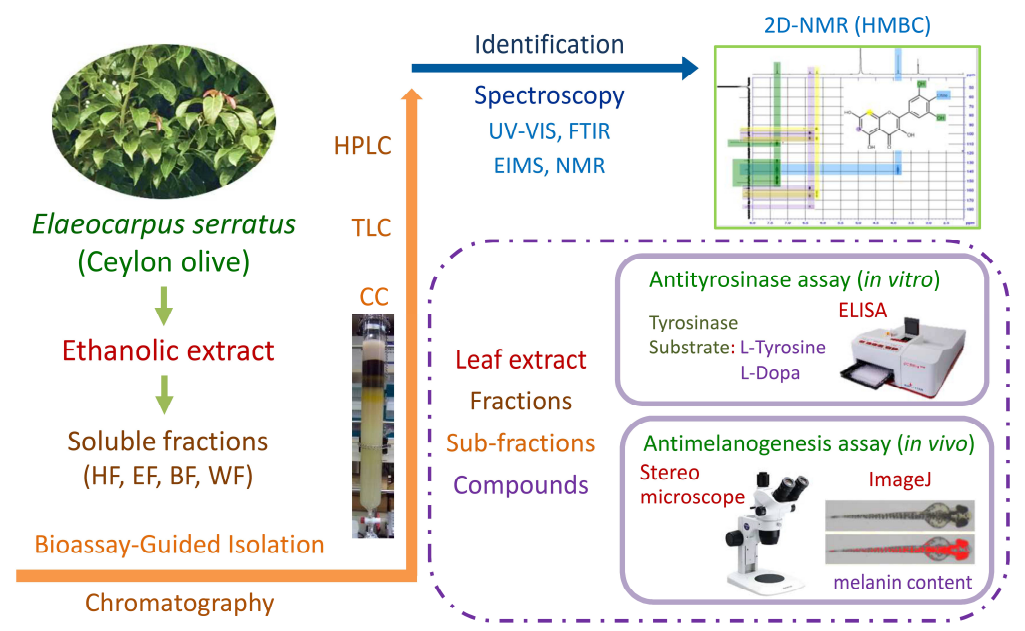

Figure 1. Schematic diagram of antimelanogenesis effects of E. serratus leaf extract.

Tyrosinase, produced by melanocyte cells, plays a key role to catalyze the complicated melanin synthesis; the exploration of tyrosinase inhibitor is one of the prominent ways to retard the melanogenesis [2,5,41]. Tyrosinase inhibition activities of leaf extract and four fractions are shown in Figure 2. When using L-tyrosine as the substrate, only the ethyl acetate soluble fraction had the inhibition effect against tyrosinase at the concentration of $400 \mu \mathrm{g} / \mathrm{mL}$. Leaf extract, ethyl acetate soluble fraction, and $n$-butanol soluble fraction exhibited the antityrosinase activity when changing L-DOPA as the substrate. Among leaf extract and four fractions, the ethyl acetate soluble fraction demonstrated the best antityrosinase activity with the $\mathrm{IC}_{50}$ values of 279.38 and $166.95 \mu \mathrm{g} / \mathrm{mL}$ when using Ltyrosine and L-DOPA as the substrate, respectively (Table 1 ). 
(a)

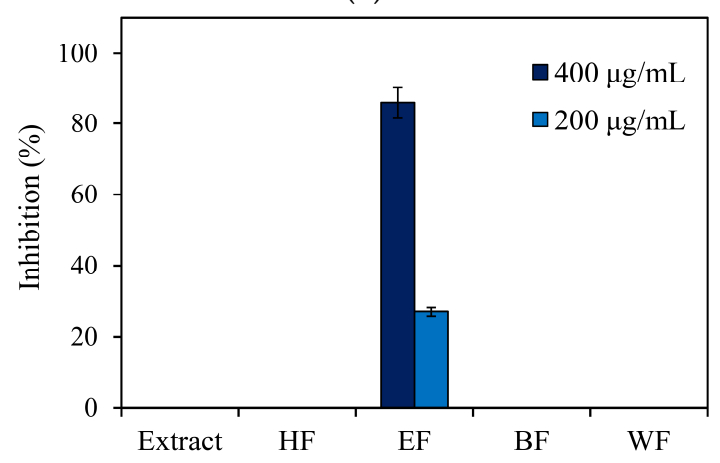

(b)

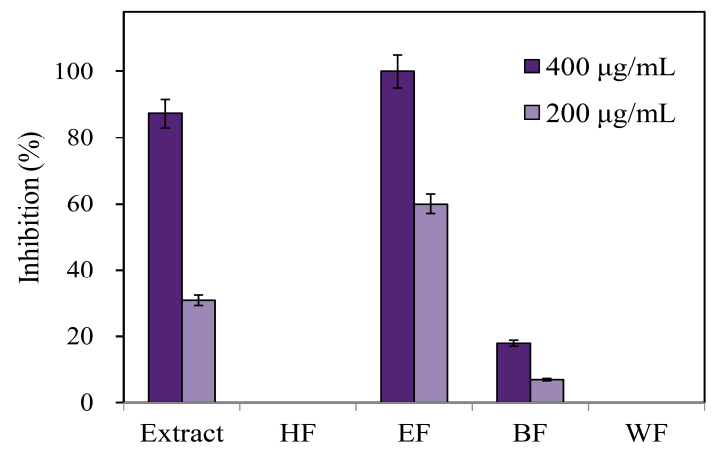

Figure 2. Antityrosinase activities of leaf extract and fractions. (a) L-Tyrosine as the substrate; (b) L-DOPA as the substrate.

Table 1. $\mathrm{IC}_{50}$ values of active subfractions against mushroom tyrosinase.

\begin{tabular}{ccc}
\hline \multirow{2}{*}{ Specimen } & \multicolumn{2}{c}{$\mathrm{IC}_{\mathbf{5 0}}(\boldsymbol{\mu g} / \mathbf{m L})$} \\
\cline { 2 - 3 } & L-Tyrosine as the Substrate & L-DOPA as the Substrate \\
\hline Extract & $-^{*}$ & $267.87 \pm 2.79^{\mathrm{B}}$ \\
EF & $279.38 \pm 3.06^{\mathrm{a}}$ & $166.95 \pm 2.38^{\mathrm{C}}$ \\
E7 & $92.45 \pm 2.06^{\mathrm{d}}$ & $126.00 \pm 3.43^{\mathrm{D}}$ \\
E8 & $153.97 \pm 4.51^{\mathrm{b}}$ & $130.77 \pm 0.80^{\mathrm{D}}$ \\
E9 & $125.13 \pm 5.01^{\mathrm{c}}$ & $157.05 \pm 1.20^{\mathrm{C}}$ \\
E10 & $172.30 \pm 2.53^{\mathrm{b}}$ & $180.64 \pm 6.61^{\mathrm{C}}$ \\
Arbutin $^{* *}$ & $147.94 \pm 1.64^{\mathrm{b}}$ & $305.58 \pm 1.28^{\mathrm{A}}$
\end{tabular}

*: > $400 \mu \mathrm{g} / \mathrm{mL}$; **: Positive control; Different letters (a-d; A-D) represent significantly different at the level of $p<$ 0.05 according to Scheffe's test.

The ethyl acetate soluble fraction was subjected to the bioassay-guided fractionation using preparative column chromatographic and thin-layer chromatographic techniques, and nineteen subfractions (E1-E19) were obtained. Among these subfractions, E7-E10 subfractions showed the higher tyrosinase inhibitory effect in both substrate assays (L-tyrosine and L-DOPA). The half-maximal inhibitory concentration $\left(\mathrm{IC}_{50}\right)$ values of active subfractions against tyrosinase are given in Table 1 . The $\mathrm{IC}_{50}$ values of all E7-E10 subfractions were below $200 \mu \mathrm{g} / \mathrm{mL}$; E7 and E9 subfractions even showed better performance compared with arbutin, which is a commercial whitening ingredient.

\subsection{Isolation and Identification of Compounds from Bioactive Subfractions}

Three compounds (ES1-3) were isolated from bioactive subfractions (E7-E10) by highperformance liquid chromatography. Gallic acid (ES1): white powder; mp $257^{\circ} \mathrm{C}$; UV $(\mathrm{MeOH}) \lambda_{\max }(\log \varepsilon) 215.5$ (3.94), 268.0 (3.46) nm; IR (KBr) $v_{\max } 3495,3416,3285,1647$, 1542 , and $1220 \mathrm{~cm}^{-1}$; EI-MS m/z $171[\mathrm{M}+\mathrm{H}]^{+}$, in agreement with the molecular formula $\mathrm{C}_{7} \mathrm{H}_{6} \mathrm{O}_{5}$. Myricetin (ES2): yellow needle; $\mathrm{mp} 358^{\circ} \mathrm{C}$; $\mathrm{UV}(\mathrm{MeOH}) \lambda_{\max }(\log \varepsilon) 252.5$ (4.43) and $374.0(4.50) \mathrm{nm}$; IR (KBr) $v_{\max } 3421,1663,1596,1520,1229,1202$, and $1171 \mathrm{~cm}^{-1}$; EI-MS $\mathrm{m} / \mathrm{z} 319.36[\mathrm{M}+\mathrm{H}]^{+}$, molecular formula $\mathrm{C}_{15} \mathrm{H}_{10} \mathrm{O}_{8}$. Mearnsetin (4'-O-methyl myricetin, ES3): yellow powder; $\mathrm{mp} 184{ }^{\circ} \mathrm{C}$; $\mathrm{UV}(\mathrm{MeOH}) \lambda_{\max }(\log \varepsilon) 259.5$ (4.21) and 364.5 (4.26) $\mathrm{nm}$; IR $(\mathrm{KBr}) v_{\max } 3409,2960,2927,2853,1661,1599,1507,1208$, and $1163 \mathrm{~cm}^{-1}$; EI-MS $\mathrm{m} / \mathrm{z} 333.0[\mathrm{M}+\mathrm{H}]^{+}$, molecular formula $\mathrm{C}_{16} \mathrm{H}_{12} \mathrm{O}_{8}$. The NMR data of these compounds are summarized in Table 2 . The chemical structures of the identified compounds are shown in Figure 3. 
Table 2. ${ }^{1} \mathrm{H},{ }^{13} \mathrm{C}$ and HMBC NMR data of compounds.

\begin{tabular}{|c|c|c|c|c|c|c|c|c|}
\hline \multirow[b]{2}{*}{ Position } & \multicolumn{2}{|c|}{ ES1 } & \multicolumn{3}{|c|}{ ES2 } & \multicolumn{3}{|c|}{ ES3 } \\
\hline & ${ }^{13} \mathrm{C}$ & ${ }^{1} \mathbf{H}$ & ${ }^{13} \mathrm{C}$ & ${ }^{1} \mathbf{H}$ & НМВС & ${ }^{13} \mathrm{C}$ & ${ }^{1} \mathbf{H}$ & НМВС \\
\hline 1 & 122.0 & & & & & & & \\
\hline 2 & 110.6 & 7.07 (s) & 148.0 & & & 147.0 & & \\
\hline 3 & 146.4 & & 136.9 & & & 138.1 & & \\
\hline 4 & 139.6 & & 177.3 & & & 177.5 & & \\
\hline 5 & 146.4 & & 162.5 & & & 104.5 & & \\
\hline 6 & 110.6 & $7.07(\mathrm{~s})$ & 99.2 & $\begin{array}{c}6.17(\mathrm{~d}, J= \\
1.95 \mathrm{~Hz})\end{array}$ & $\begin{array}{l}\text { C-5, C-7, } \\
\text { C-8, C-10 }\end{array}$ & 162.5 & $\begin{array}{c}6.17(\mathrm{~d}, J= \\
1.80 \mathrm{~Hz})\end{array}$ & $\begin{array}{l}\text { C-5, C-7, } \\
\text { C- } 8, \text { C- } 10\end{array}$ \\
\hline 7 & 170.4 & & 165.6 & & & 99.4 & & \\
\hline 8 & & & 94.4 & $\begin{array}{c}6.37(\mathrm{~d}, J= \\
1.95 \mathrm{~Hz})\end{array}$ & $\begin{array}{l}\text { C-6, C-7, } \\
\text { C-9, C-10 }\end{array}$ & 166.2 & $\begin{array}{c}6.37(\mathrm{~d}, J= \\
1.80 \mathrm{~Hz})\end{array}$ & $\begin{array}{l}\text { C-6, C-7, } \\
\text { C-9, C-10 }\end{array}$ \\
\hline 9 & & & 158.2 & & & 94.5 & & \\
\hline 10 & & & 104.5 & & & 158.3 & & \\
\hline $1^{\prime}$ & & & 123.1 & & & 128.0 & & \\
\hline $2^{\prime} / 6^{\prime}$ & & & 108.5 & 7.33 (s) & $\begin{array}{c}C-2, C-1^{\prime}, \\
C-3^{\prime} / C-5^{\prime}, \\
C-4^{\prime}\end{array}$ & 108.6 & 7.30(s) & $\begin{array}{c}\mathrm{C}-2, \mathrm{C}-1^{\prime}, \\
\mathrm{C}-3^{\prime} / \mathrm{C}-5^{\prime} \\
\mathrm{C}-4^{\prime}\end{array}$ \\
\hline $3^{\prime} / 5^{\prime}$ & & & 146.7 & & & 151.7 & & \\
\hline $4^{\prime}$ & & & 137.4 & & & 138.5 & & \\
\hline $7^{\prime}$ & & & & & & 60.8 & $3.87(\mathrm{~s})$ & $C-4^{\prime}$ \\
\hline
\end{tabular}<smiles>O=C(O)c1cc(O)c(O)c(O)c1</smiles>

Gallic acid

(ES1)<smiles>O=c1c(O)c(-c2cc(O)c(O)c(O)c2)oc2cc(O)cc(O)c12</smiles>

Myricetin

(ES2)<smiles>COc1c(O)cc(-c2oc3cc(O)cc(O)c3c(=O)c2O)cc1O</smiles>

(ES3)

Figure 3. Chemical structures of isolated compounds.

Among these compounds, gallic acid is a phenolic acid; myricetin and mearnsetin belong to the flavonoids. The contents of each compound in ethyl acetate soluble fraction and E7-E10 subfractions are listed in Table 3. The E7 subfraction was rich in mearnsetin $(433.38 \mathrm{mg} / \mathrm{g})$; the E8 subfraction primary contained gallic acid (417.64 mg/g). The major constituent of subfractions E9 and E10 was myricetin ( 406.41 and $336.41 \mathrm{mg} / \mathrm{g}$, respectively). The contents of three compounds in the ethyl acetate soluble fraction were $59.72 \mathrm{mg} / \mathrm{g}$ (gallic acid), $45.21 \mathrm{mg} / \mathrm{g}$ (myricetin), and $22.66 \mathrm{mg} / \mathrm{g}$ (mearnsetin).

Table 3. Contents of three compounds in the ethyl acetate soluble fraction and active subfractions.

\begin{tabular}{cccc}
\hline \multirow{2}{*}{ Specimen } & \multicolumn{3}{c}{ Content $(\mathbf{m g} / \mathbf{g})$} \\
\cline { 2 - 4 } & Gallic Acid & Myricetin & Mearnsetin \\
\hline EF & $59.72 \pm 1.08$ & $45.21 \pm 0.19$ & $22.66 \pm 0.30$ \\
E7 & $-^{*}$ & - & $433.38 \pm 3.02$ \\
E8 & $417.64 \pm 8.04$ & $132.83 \pm 1.56$ & $136.48 \pm 3.33$ \\
E9 & $235.04 \pm 7.08$ & $406.41 \pm 0.41$ & $50.62 \pm 1.94$ \\
E10 & - & $336.41 \pm 12.12$ & - \\
\hline
\end{tabular}

*: Trace or none.

\subsection{Antityrosinase Activity and Enzyme Kinetic Study of Isolated Compounds}

Antityrosinase activity of these compounds from active subfractions were represented in Table 4. When using the L-tyrosine as the substrate, the order of antityrosinase activity 
of examined compounds was mearnsetin $>$ myricetin $>$ gallic acid $>$ arbutin; mearnsetin had the best inhibition effect with the $\mathrm{IC}_{50}$ value of $56.57 \mu \mathrm{g} / \mathrm{mL}(0.17 \mathrm{mM})$. Similar results were observed in the L-DOPA used as the substrate; the efficacy of three phytochemicals was superior to that of arbutin.

Table 4. $\mathrm{IC}_{50}$ values of compounds against mushroom tyrosinase.

\begin{tabular}{ccc}
\hline \multirow{2}{*}{ Specimen } & \multicolumn{2}{c}{ IC $_{\mathbf{5 0}}$} \\
\cline { 2 - 3 } & L-Tyrosine as the Substrate & L-DOPA as the Substrate \\
\hline \multirow{2}{*}{ Gallic acid } & $92.40 \pm 4.12^{*, \mathrm{~b}}$ & $106.91 \pm 2.19^{\mathrm{C}}$ \\
& $(0.54 \pm 0.02)^{* * *}$ & $(0.63 \pm 0.01)$ \\
Myricetin & $74.20 \pm 7.10^{\mathrm{c}}$ & $190.78 \pm 2.09^{\mathrm{B}}$ \\
& $(0.23 \pm 0.02)^{\mathrm{d}}$ & $(0.60 \pm 0.01)$ \\
Mearnsetin & $56.57 \pm 1.26^{\mathrm{d}}$ & $118.92 \pm 2.91^{\mathrm{C}}$ \\
& $(0.17 \pm 0.01)$ & $(0.36 \pm 0.01)$ \\
Arbutin & $147.94 \pm 1.64^{\mathrm{a}}$ & $305.58 \pm 1.28^{\mathrm{A}}$ \\
& $(0.54 \pm 0.01)$ & $(1.12 \pm 0.01)$ \\
\hline
\end{tabular}

${ }^{*}: \mu \mathrm{g} / \mathrm{mL}^{* *}: \mathrm{mM} ;{ }^{* * *}$ : Positive control; Different letters $(\mathrm{a}-\mathrm{d} ; \mathrm{A}-\mathrm{C})$ represent significantly different at the level of $p<0.05$ according to Scheffe's test.

A true enzyme inhibitor contains four modes of inhibition, including competitive, uncompetitive, mixed type (both competitive and uncompetitive), and noncompetitive [12]. Kinetic constants, $\mathrm{K}_{\mathrm{m}}$ and $\mathrm{V}_{\max }$, are determined by the enzyme initial rate at the different substrate concentrations in the Lineweaver-Burk plot; the intersect at the $y$-axis is equivalent to $1 / \mathrm{V}_{\max }$, and the intersect at the $x$-axis is $-1 / \mathrm{K}_{\mathrm{m}}$. In the enzyme kinetic study of terpenoid compounds from the citrus peel essential oil against tyrosinase, citral acted as a noncompetitive inhibitor, and myrcene was a competitive inhibitor [36]. The inhibition mechanism of 3,7-dioleylquercetin against mushroom tyrosinase was through the competitive inhibition model to suppress the production of melanin [42].

The inhibition type on tyrosinase of three phytochemicals was elucidated by an in vitro enzyme kinetic study. Figure 4 showed the Lineweaver-Burk plot (double reciprocal plot) of mearnsetin. In the analyses of both substrates, L-tyrosine and L-Dopa, the linear regression line of different concentrations of mearnsetin had the same intercept on the $y$-axis and the increasing slope. The kinetic parameters of gallic acid, myricetin, and mearnsetin are summarized in Table 5. In the presence of gallic acid or mearnsetin, an increase in $\mathrm{K}_{\mathrm{m}}$ and a constant in $V_{\max }$ were observed, indicating that both gallic acid and mearnsetin were the competitive inhibitor of tyrosinase. It indicated that gallic acid and mearnsetin could bind to free tyrosinase with high affinity and prevent substrate (L-tyrosine or L-DOPA) binding to the active site of tyrosinase. Myricetin was found to be a mixed-type inhibitor, containing competitive and uncompetitive inhibition, since $K_{m}$ was increased and $V_{\max }$ was decreased. Uncompetitive inhibition demonstrated that compounds bind to the tyrosinase-substrate complex but not to the free tyrosinase. 
(a)

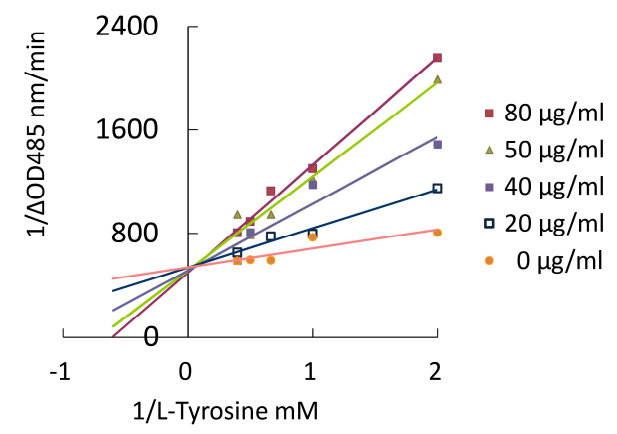

(b)

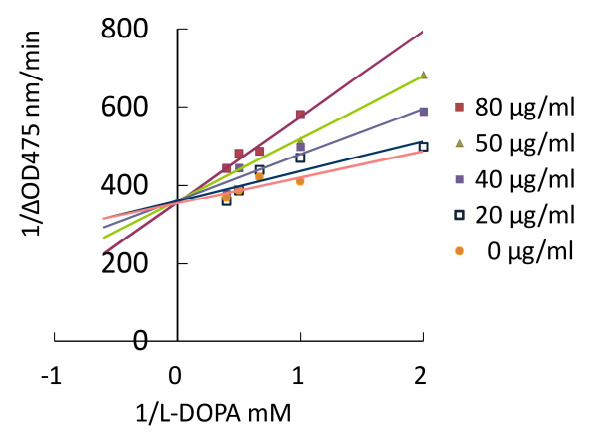

Figure 4. Lineweaver-Burk plots of mearnsetin. (a) L-Tyrosine as the substrate; (b) L-DOPA as the substrate.

Table 5. Kinetic parameters of phytochemicals against tyrosinase in enzyme kinetic study.

\begin{tabular}{|c|c|c|c|c|c|c|c|c|c|}
\hline \multirow{2}{*}{ Compound } & \multirow{2}{*}{ Substrate } & \multirow{2}{*}{$\begin{array}{c}\text { Kinetic } \\
\text { Parameter }\end{array}$} & \multicolumn{5}{|c|}{ Concentration $(\mu \mathrm{g} / \mathrm{mL})$} & \multirow{2}{*}{ Potential } & \multirow{2}{*}{$\begin{array}{c}\text { Inhibition } \\
\text { Type }\end{array}$} \\
\hline & & & $\mathbf{0}$ & 40 & 50 & 80 & 100 & & \\
\hline \multirow{4}{*}{$\begin{array}{l}\text { Gallic } \\
\text { acid }\end{array}$} & \multirow{2}{*}{ L-Tyrosine } & $\mathrm{V}_{\max }$ & 0.0011 & 0.0012 & 0.0012 & 0.0012 & 0.0011 & - & \multirow{2}{*}{ Competitive } \\
\hline & & $\mathrm{K}_{\mathrm{m}}$ & 0.0484 & 0.1458 & 0.3003 & 0.7299 & 0.9054 & $\uparrow$ & \\
\hline & \multirow{2}{*}{ L-DOPA } & $\mathrm{V}_{\max }$ & 0.0035 & 0.0034 & 0.0034 & 0.0034 & 0.0035 & - & \multirow{2}{*}{ Competitive } \\
\hline & & $\mathrm{K}_{\mathrm{m}}$ & 0.0733 & 0.1592 & 0.2788 & 0.4385 & 0.9462 & $\uparrow$ & \\
\hline \multirow{4}{*}{ Myricetin } & \multirow{2}{*}{ L-Tyrosine } & $\mathrm{V}_{\max }$ & 0.0012 & 0.0010 & 0.0009 & 0.0008 & 0.0007 & $\downarrow$ & \multirow{2}{*}{ Mixed } \\
\hline & & $\mathrm{K}_{\mathrm{m}}$ & 0.1415 & 0.2997 & 0.3741 & 0.3813 & 0.4225 & $\uparrow$ & \\
\hline & \multirow[b]{2}{*}{ L-DOPA } & $\mathrm{V}_{\max }$ & 0.0035 & 0.0028 & 0.0025 & 0.0023 & 0.0020 & $\downarrow$ & \multirow{2}{*}{ Mixed } \\
\hline & & $\mathrm{K}_{\mathrm{m}}$ & 0.1422 & 0.2877 & 0.3132 & 0.3920 & 0.4068 & $\uparrow$ & \\
\hline \multirow{4}{*}{ Mearnsetin } & \multirow{2}{*}{ L-Tyrosine } & $\mathrm{V}_{\max }$ & 0.0018 & 0.0018 & 0.0019 & 0.0019 & 0.0020 & - & \multirow{2}{*}{ Competitive } \\
\hline & & $\mathrm{K}_{\mathrm{m}}$ & 0.2673 & 0.5567 & 0.9953 & 1.3976 & 1.6487 & $\uparrow$ & \\
\hline & \multirow{2}{*}{ L-DOPA } & $\mathrm{V}_{\max }$ & 0.0028 & 0.0028 & 0.0028 & 0.0028 & 0.0028 & - & \multirow{2}{*}{ Competitive } \\
\hline & & $\mathrm{K}_{\mathrm{m}}$ & 0.1862 & 0.2114 & 0.3217 & 0.4399 & 0.6136 & $\uparrow$ & \\
\hline
\end{tabular}

\subsection{Antimelanogenesis Effects of Extract, Fractions, and Isolated Phytochemicals}

Zebrafish (Danio rerio) is a novel and valid model organism for melanogenesis research in recent studies [18-21,40]. The antimelanogenesis effects of leaf extract and four fractions in the in vivo zebrafish assay are shown in Figure 5. The leaf extract and ethyl acetate soluble fraction exhibited good performance in the inhibition of melanin formation in zebrafish embryos. At a concentration of $200 \mu \mathrm{g} / \mathrm{mL}$, the leaf extract and ethyl acetate soluble fraction inhibited $27.72 \%$ and $35.60 \%$ of melanin production of zebrafish embryos, respectively. All treatments did not influence the growth of zebrafish embryo with a survival rate of $100 \%$.

Figure 6 presented the effects of compounds and positive controls, PTU and arbutin, on the melanogenesis of zebrafish at a concentration of $50 \mu \mathrm{M}$. PTU is a strong tyrosinase inhibitor to prevent the melanin production, while arbutin is a commercial skin-whitening agent; both positive controls could reduce the melanin formation in zebrafish. Among three phytochemicals, myricetin showed the slight melanin inhibition effect, while mearnsetin had the better melanogenesis inhibition activity in zebrafish.

The effective concentrations of melanogenesis inhibition activity in zebrafish of compounds are listed in Table 6 . IC 50 values of PTU and arbutin were $26.29 \mu \mathrm{M}$ and $323.69 \mu \mathrm{M}$, respectively. The order of antimelanogenesis activity of examined compounds was PTU > mearnsetin $>$ arbutin and myricetin $>$ gallic acid. Mearnsetin exhibited the best efficacy with an IC50 value of $121.01 \mu \mathrm{M}$ among examined phytochemicals. 


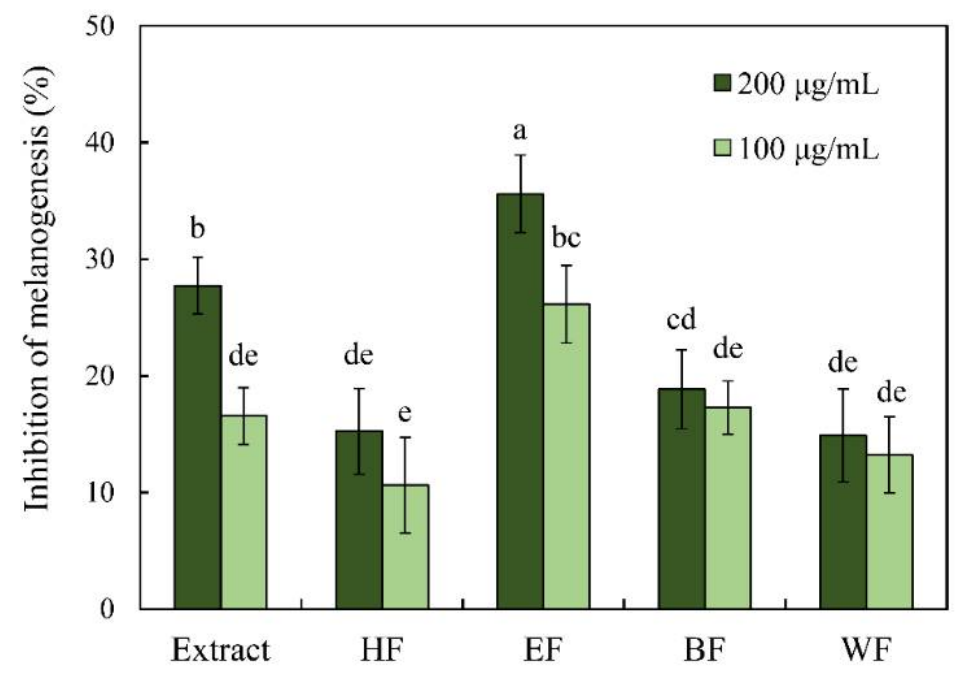

Figure 5. Inhibitory effect of leaf extract and its fractions on the melanogenesis of zebrafish embryo. Different letters (a-e) represent significantly different at the level of $p<0.05$ according to Scheffe's test.

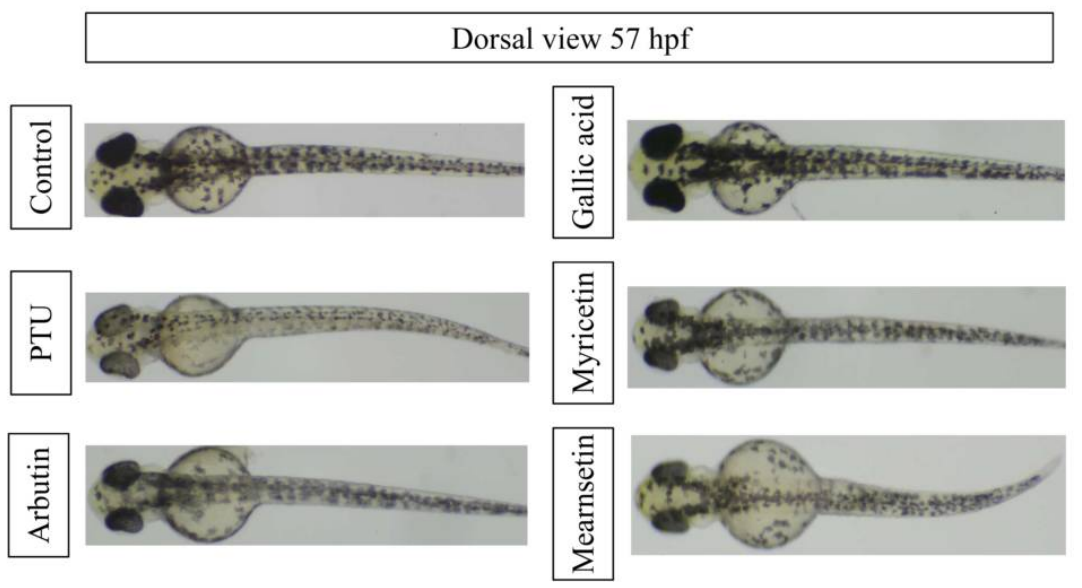

Figure 6. Effects of compounds on melanogenesis of zebrafish at a concentration of $50 \mu \mathrm{M}$.

Table 6. $\mathrm{IC}_{50}$ values of melanogenesis inhibition activity in zebrafish of compounds.

\begin{tabular}{cc}
\hline Specimen & IC $_{50}(\mu \mathbf{M})$ \\
\hline Gallic acid & $-{ }^{* *}$ \\
Myricetin & $349.96 \pm 42.67^{\mathrm{a}}$ \\
Mearnsetin $^{*}$ & $121.01 \pm 0.96^{\mathrm{b}}$ \\
PTU $^{*}$ & $26.29 \pm 4.17^{\mathrm{c}}$ \\
Arbutin $^{*}$ & $323.69 \pm 19.77^{\mathrm{a}}$ \\
\hline
\end{tabular}

${ }^{*}$ Positive control; ${ }^{* *}>400 \mu \mathrm{M}$; Different letters (a-c) represent significantly different at the level of $p<0.05$ according to Scheffe's test.

\section{Conclusions}

The melanogenesis inhibition effect and antityrosinase activity of leaf extract from Ceylon olive (E. serratus) were evaluated in this study. Among leaf extract and its four fractions, ethyl acetate soluble fraction had the best antityrosinase activity. Phytochemicals, including gallic acid, myricetin and mearnsetin, were isolated and identified from the active subfractions by bioassay-guided chromatography and spectral analyses. The order of antityrosinase activity of these compounds was mearnsetin $>$ myricetin $>$ gallic acid. The in vitro enzyme kinetic study reveals that gallic acid and mearnsetin were competitive inhibitors of tyrosinase, and myricetin was a mixed-type inhibitor. Results from the zebrafish 
in vivo assay revealed that an ethyl acetate soluble fraction and three phytochemicals possessed significant melanogenesis inhibition effects. The antimelanogenesis effect of mearnsetin was superior to that of the positive control, arbutin, in zebrafish.

Author Contributions: Conceptualization, I.-H.L., S.-T.C. and H.-T.C.; methodology, C.-Y.H., I.-H.L., H.-T.C. and X.-Z.H.; software, X.-Z.H. and C.-Y.H.; formal analysis and investigation, C.-Y.H., I.H.L., X.-Z.H., H.-J.C. and H.-T.C.; writing-original draft preparation, H.-T.C., M.-L.C. and Y.-T.H.; writing-review and editing, H.-T.C. and M.-L.C. All authors have read and agreed to the published version of the manuscript.

Funding: This research received no external funding.

Institutional Review Board Statement: The study was conducted according to the 3R principles of laboratory animal care and use.

Informed Consent Statement: Informed consent was obtained from all subjects involved in the study.

Data Availability Statement: The data are available are available from the corresponding author on reasonable request.

Acknowledgments: The authors thank the Instrumentation Center of National Taiwan University for spectral analyses.

Conflicts of Interest: The authors declare no conflict of interest.

\section{References}

1. Pillaiyar, T.; Manickam, M.; Jung, S.H. Inhibitors of melanogenesis: A patent review (2009-2014). Expert Opin. Ther. Pat. 2015, 25, 775-788. [CrossRef] [PubMed]

2. Pillaiyar, T.; Manickam, M.; Namasivayam, V. Skin whitening agents: Medicinal chemistry perspective of tyrosinase inhibitors. J. Enzym. Inhib. Med. Chem. 2017, 32, 403-425. [CrossRef]

3. Yardman-Frank, J.M.; Fisher, D.E. Skin pigmentation and its control: From ultraviolet radiation to stem cells. Exp. Dermatol. 2021, 30, 560-561. [CrossRef]

4. Kim, Y.J.; Uyama, H. Tyrosinase inhibitors from natural and synthetic sources: Structure, inhibition mechanism and perspective for the future. Cell. Mol. Life Sci. 2005, 62, 1707-1723. [CrossRef] [PubMed]

5. Solano, F.; Briganti, S.; Picardo, M.; Ghanem, G. Hypopigmenting agents: An updated review on biological, chemical and clinical aspects. Pigment Cell Res. 2006, 19, 550-571. [CrossRef] [PubMed]

6. Riley, P.A. Hydroxyanisole depigmentation: In-Vivo studies. J. Pathol. 1969, 97, 185-191. [CrossRef] [PubMed]

7. Lee, Y.; Kumar, S.; Kim, S.H.; Seong, K.Y.; Lee, H.; Kim, C.; Jung, Y.S.; Yang, S.Y. Odorless glutathione microneedle patches for skin whitening. Pharmaceutics 2020, 12, 100. [CrossRef] [PubMed]

8. Tan, S.K.; Sim, C.S.; Goh, C.L. Hydroquinone-induced exogenous ochronosis in Chinese-two case reports and a review. Int. J. Dermatol. 2008, 47, 639-640. [CrossRef]

9. Burdock, G.A.; Soni, M.G.; Carabin, I.G. Evaluation of health aspects of kojic acid in food. Regul. Toxicol. Pharmacol. 2001, 33, 80-101. [CrossRef]

10. Cheng, S.L.; Huang, L.R.; Sheu, J.N.; Chen, S.T.; Sinchaikul, S.; Tsay, G.J. Toxicogenomics of kojic acid on gene expression profiling of A375 human malignant melanoma cells. Biol. Pharm. Bull. 2006, 29, 655-669. [CrossRef]

11. Chen, W.C.; Tseng, T.S.; Hsiao, N.W.; Lin, Y.L.; Wen, Z.H.; Tsai, C.C.; Lee, Y.C.; Lin, H.H.; Tsai, K.C. Discovery of highly potent tyrosinase inhibitor, $\mathrm{T} 1$, with significant anti-melanogenesis ability by zebrafish in vivo assay and computational molecular modeling. Sci. Rep. 2015, 5, 7995. [CrossRef]

12. Zolghadri, S.; Bahrami, A.; Khan, M.T.H.; Munoz-Munoz, J.; Garcia-Molina, F.; Garcia-Canovas, F.; Saboury, A.A. A comprehensive review on tyrosinase inhibitors. J. Enzym. Inhib. Med. Chem. 2019, 34, 279-309. [CrossRef]

13. Panichakul, T.; Rodboon, T.; Suwannalert, P.; Tripetch, C.; Rungruang, R.; Boohuad, N.; Youdee, P. Additive effect of a combination of Artocarpus lakoocha and Glycyrrhiza glabra extracts on tyrosinase inhibition in melanoma B16 cells. Pharmaceuticals 2020, 13, 310. [CrossRef] [PubMed]

14. Lee, T.H.; Seo, J.O.; Baek, S.H.; Kim, S.Y. Inhibitory effects of resveratrol on melanin synthesis in ultraviolet B-induced pigmentation in guinea pig skin. Biomol. Ther. 2014, 22, 35-40. [CrossRef] [PubMed]

15. Fan, M.H.; Zhang, G.W.; Hu, X.; Xu, X.M.; Gong, D.M. Quercetin as a tyrosinase inhibitor: Inhibitory activity, conformational change and mechanism. Food Res. Int. 2017, 100, 226-233. [CrossRef] [PubMed]

16. Qian, W.H.; Liu, W.Y.; Zhu, D.; Cao, Y.L.; Tang, A.F.; Gong, G.M.; Su, H. Natural skin-whitening compounds for the treatment of melanogenesis (Review). Exp. Ther. Med. 2020, 20, 173-185. [CrossRef]

17. No, J.K.; Soung, D.Y.; Kim, Y.J.; Shim, K.H.; Jun, Y.S.; Rhee, S.H.; Yokozawa, T.; Chung, H.Y. Inhibition of tyrosinase by green tea components. Life Sci. 1999, 65, 241-246. [CrossRef] 
18. Park, H.Y.; Song, K.H.; Jung, P.M.; Kim, J.E.; Ro, H.; Kim, M.Y.; Ma, J.Y. Inhibitory effect of arctigenin from Fructus arctii extract on melanin synthesis via repression of tyrosinase expression. Evid. Based Complement. Alternat. Med. 2013, 2013, 965312. [CrossRef]

19. Lee, D.Y.; Cha, B.J.; Lee, Y.S.; Kim, G.S.; Noh, H.J.; Kim, S.Y.; Kang, H.C.; Kim, J.H.; Baek, N.I. The potential of minor ginsenosides isolated from the leaves of Panax ginseng as inhibitors of melanogenesis. Int. J. Mol. Sci. 2015, 16, 1677-1690. [CrossRef]

20. Lee, D.Y.; Lee, J.S.; Jeong, Y.T.; Byun, G.H.; Kim, J.H. Melanogenesis inhibition activity of floralginsenoside A from Panax ginseng berry. J. Ginseng Res. 2017, 41, 602-607. [CrossRef]

21. Lee, D.Y.; Kim, H.G.; Lee, Y.G.; Kim, J.H.; Lee, J.W.; Choi, B.R.; Jang, I.B.; Kim, G.S.; Baek, N.I. Isolation and quantification of ginsenoside rh23, a new anti-melanogenic compound from the leaves of Panax Ginseng. Molecules 2018, 23, 267. [CrossRef]

22. Jayasinghe, L.; Amarasinghe, N.R.; Arundathie, B.G.; Rupasinghe, G.K.; Jayatilake, N.H.; Fujimoto, Y. Antioxidant flavonol glycosides from Elaeocarpus serratus and Filicium decipiens. Nat. Prod. Res. 2012, 26, 717-721. [CrossRef]

23. Sharker, S.M.D.; Shahid, I.J. Assessment of antibacterial and cytotoxic activity of some locally used medicinal plants in Sundarban mangrove forest region. J. Pharm. Pharmacol. 2010, 4, 66-69.

24. Vassallo, A.; Armentano, M.F.; Miglionico, R.; Caddeo, C.; Chirollo, C.; Gualtieri, M.J.; Ostuni, A.; Bisaccia, F.; Faraone, I.; Milella, L. Hura crepitans L. extract: Phytochemical characterization, antioxidant activity, and nanoformulation. Pharmaceutics 2020, 12, 553. [CrossRef] [PubMed]

25. Yen, P.L.; Wu, C.L.; Chang, S.T.; Huang, S.L.; Chang, H.T. Antioxidative lignans from phytochemical extract of Calocedrus formosana Florin. BioResources 2012, 7, 4122-4131.

26. Li, W.H.; Chang, S.T.; Chang, S.C.; Chang, H.T. Isolation of antibacterial diterpenoids from Cryptomeria japonica bark. Nat. Prod. Res. 2008, 22, 1085-1093. [CrossRef]

27. Starek, M.; Plenis, A.; Zagrobelna, M.; Dabrowska, M. Assessment of lipophilicity descriptors of selected NSAIDS obtained at different TLC stationary phases. Pharmaceutics 2021, 13, 440. [CrossRef] [PubMed]

28. Santonocito, D.; Granata, G.; Geraci, C.; Panico, A.; Siciliano, E.A.; Raciti, G.; Puglia, C. Carob seeds: Food waste or source of bioactive compounds? Pharmaceutics 2020, 12, 1090. [CrossRef]

29. Wu, C.C.; Wu, C.L.; Huang, S.L.; Chang, H.T. Antifungal activity of liriodenine from Michelia formosana heartwood against wood-rotting fungi. Wood Sci. Technol. 2012, 46, 737-747. [CrossRef]

30. Gutierrez-Macias, P.; Peralta-Cruz, J.; Borja-de-la-Rosa, A.; Barragan-Huerta, B.E. Peltomexicanin, a peltogynoid quinone methide from Peltogyne mexicana Martinez purple heartwood. Molecules 2016, 21, 186. [CrossRef]

31. Nunes, A.; Marto, J.; Gonçalves, L.M.; Simões, S.; Félix, R.; Ascenso, A.; Lopes, F.; Ribeiro, H.M. Novel and modified neutrophil elastase inhibitor loaded in topical formulations for psoriasis management. Pharmaceutics 2020, 12, 358. [CrossRef]

32. Silvestre, G.F.G.; Lucena, R.P.; Oliveira, G.D.; Pereira, H.N.; Dias, J.A.B.; Souza, I.A.; Alves, H.S. Anti-tumor and anti-inflammatory activity in vivo of Apodanthera congestiflora Cogn. (Cucurbitaceae). Pharmaceutics 2021, 13, 743. [CrossRef] [PubMed]

33. Masuda, T.; Yamashita, D.; Takeda, Y.; Yonemori, S. Screening for tyrosinase inhibitors among extracts of seashore plants and identification of potent inhibitors from Garcinia subelliptica. Biosci. Biotechnol. Biochem. 2005, 69, 197-201. [CrossRef]

34. Axiotis, E.; Petrakis, E.A.; Halabalaki, M.; Mitakou, S. Phytochemical profile and biological activity of endemic Sideritis sipylea Boiss. in North Aegean Greek islands. Molecules 2020, 25, 2022. [CrossRef]

35. López, V.; Les, F.; Mevi, S.; Wandjou, J.G.N.; Cásedas, G.; Caprioli, G.; Maggi, F. Phytochemicals and enzyme inhibitory capacities of the methanolic extracts from the Italian apple cultivar Mela Rosa dei Monti Sibillini. Pharmaceuticals 2020, 13, 127. [CrossRef]

36. Matsuura, R.; Ukeda, H.; Sawamura, M. Tyrosinase inhibitory activity of citrus essential oils. J. Agric. Food Chem. 2006, 54, 2309-2313. [CrossRef]

37. Alam, M.B.; Seo, B.J.; Zhao, P.; Lee, S.H. Anti-melanogenic activities of Heracleum moellendorffii via ERK1/2-mediated MITF downregulation. Int. J. Mol. Sci. 2016, 17, 1844. [CrossRef] [PubMed]

38. Angelis, A.; Hubert, J.; Aligiannis, N.; Michalea, R.; Abedini, A.; Nuzillard, J.M.; Gangloff, S.C.; Skaltsounis, A.L.; Renault, J.H. Bio-guided isolation of methanol-soluble metabolites of common spruce (Picea abies) bark by-products and investigation of their dermo-cosmetic properties. Molecules 2016, 21, 1586. [CrossRef] [PubMed]

39. Chaita, E.; Lambrinidis, G.; Cheimonidi, C.; Agalou, A.; Beis, D.; Trougakos, I.; Mikros, E.; Skaltsounis, A.L.; Aligiannis, N. Anti-melanogenic properties of greek plants. A novel depigmenting agent from Morus alba wood. Molecules 2017, $22,514$. [CrossRef] [PubMed]

40. Jang, D.K.; Pham, C.H.; Lee, I.S.; Jung, S.H.; Jeong, J.H.; Shin, H.S.; Yoo, H.M. Anti-melanogenesis activity of 6-Oisobutyrylbritannilactone from Inula britannica on B16F10 melanocytes and in vivo zebrafish models. Molecules 2020, $25,3887$. [CrossRef]

41. Halaban, R.; Patton, R.S.; Cheng, E.; Svedine, S.; Trombetta, E.S.; Wahl, M.L.; Ariyan, S.; Hebert, D.N. Abnormal acidification of melanoma cells induces tyrosinase retention in the early secretory pathway. J. Biol. Chem. 2002, 277, 14821-14828. [CrossRef] [PubMed]

42. Choi, M.H.; Yang, S.H.; Kim, D.S.; Kim, N.D.; Shin, H.J.; Liu, K. Novel quercetin derivative of 3,7-dioleylquercetin shows less toxicity and highly potent tyrosinase inhibition activity. Int. J. Mol. Sci. 2021, 22, 4264. [CrossRef] [PubMed] 